\title{
The Risk Atlas of Mexico City, Mexico: a tool for decision-making and disaster prevention
}

\author{
David A. Novelo-Casanova ${ }^{1}$ - Gerardo Suárez ${ }^{1}$ - Enrique Cabral-Cano ${ }^{2}$. \\ Enrique A. Fernández-Torres ${ }^{3}$. Oscar A. Fuentes-Mariles ${ }^{4}$. Emre Havazli ${ }^{5}$. \\ Miguel Á. Jaimes ${ }^{6}$. Erika D. López-Espinoza ${ }^{7}$. Ana Lillian Martin-Del Pozzo ${ }^{8}$. \\ Wendy V. Morales-Barrera ${ }^{9} \cdot$ Hipólito L. Morales-Rodríguez ${ }^{4} \cdot$ Amiel Nieto-Torres $^{3}$. \\ Sergio R. Rodríguez-Elizarrarás ${ }^{9} \cdot$ Darío Solano-Rojas $^{10} \cdot$ Victor M. Velasco-Herrera $^{11}$
}

Received: 23 May 2021 / Accepted: 27 September 2021 / Published online: 8 October 2021

(C) The Author(s) 2021

\begin{abstract}
We present a Risk Atlas of Mexico City based on a Geographical Information System (RAGIS). We identified the prevalent social risk to the more relevant hazards in Mexico City (CDMX): earthquakes, volcanic eruptions, floods, landslides, forest fires, and land subsidence. A total of 274 shape-file maps were generated in this project. Seismic hazard was estimated for return periods (RP) of 20,125, 250, and 475 years. Three areas in central and northwestern CDMX were identified along the Younger Chichinautzin Monogenetic Volcanic Field with a high probability of forming a new volcano. Subsidence is concentrated to the east and southeast of CDMX, where subsidence rates are among the highest worldwide. Flooding events were estimated for RP of 2, 5, 10, 50, and 100 years, and most of them are concentrated in the central and northern sectors of the city. During the dry season (December-April), southern CDMX has very high probability of forest fire occurrence. There is high susceptibility of landslides on the west and southwest of the city. The goals of this RA-GIS are to provide a tool to the local and federal authorities and all organizations responsible for disaster prevention and mitigation to: (1) improve the knowledge of the potential physical and social impact of local hazards; (2) provide elements for disaster prevention, mitigation, preparedness, and response; (3) benefit decision-makers with robust risk data; (4) provide information for land-use planning; and (5) support further research to reduce the impact of disasters caused by natural phenomena.
\end{abstract}

Keywords Mexico City · Hazard · Vulnerability · Risk · Risk Atlas · Disaster prevention · Mexico

David A. Novelo-Casanova dnovelo@geofisica.unam.mx

Extended author information available on the last page of the article 


\section{Introduction}

The reason behind Mexico City's high level of exposure to natural phenomena lies at the core of its history. Mexico City (CDMX) sits in an endorheic basin, where precipitation formed a set of interconnected lakes fed by rivers flowing from the surrounding mountains (Santoyo et al. 2005; Sosa-Rodríguez 2010). CDMX was founded on the remains of the old Aztec capital. The Aztecs built their city on an island in the middle of the lake. After the Spanish conquest, the Spaniards decided to build the new capital on the ruins of the old Aztec city and began to drain and landfill the surrounding lakes. They also disregarded maintenance of the system of dikes and aqueducts built by the original inhabitants to control flooding (Levi 1990; Sosa-Rodríguez 2010). As a result, the newly founded city suffered frequent inundations in 1555, 1604, 1607, and 1629 (Hoberman 1974). After the 1607 catastrophic floods, the authorities ordered the construction of a channel to the northeast of the city to drain the lakes and to provide an outlet during heavy rains (Boyer 1975; Scaletti Cárdenas 2018).

Since those early days, major engineering projects have been undertaken to alleviate flooding of the city. Most of the original lakes have been drained, and CDMX gradually grew on the soft clay sediments of the old lakebed. This soft, water-saturated subsoil is the cause behind many of the hazards now faced by the city. For example, although CDMX lies about $350 \mathrm{~km}$ from the subduction zone, where the largest and more frequent earthquakes originate, it is severely affected by strong shaking due to the local amplification of seismic waves (e.g., Ordaz and Singh 1992). Also, the subsidence rates observed in CDMX, considered to be among the largest in the world, are due to the sinking of the lakebed due to water extraction (López-Quiroz et al. 2009; Cabral-Cano et al. 2008; Osmanoglu et al. 2011). Additionally, soil fractures result from the differential subsidence of the ground (Auvinet et al. 2013).

As a result of the subsoil characteristics, the population, infrastructure, and critical facilities are highly exposed to earthquakes, land subsidence and flooding. In addition, CDMX is in the Trans-Mexican Volcanic Belt (TMVB) and is affected by volcanic activity. Thus, CDMX faces important challenges to contend with future disastrous situations. Digital maps are important interactive tools to visualize and compare the spatial distribution of the population, buildings, and infrastructure exposed to various hazards.

The purpose here is to present a digital atlas of hazards and social risk of CDMX developed in a Geographic Information System that from now on we call RA-GIS. Also, because risk is a spatially dependent phenomenon, emergency managers and the public require a proper visualization instrument such as a GIS. The main objectives of the RA-GIS are to make authorities, citizens, and the media aware of the levels of natural hazards and risks to which the city is exposed with the purpose of providing the necessary elements to establish preventive and remedial actions. This RA-GIS can also serve as a guide for future land use and development plans, to promote scientific research on the subject and to strengthen the culture of disaster prevention in society.

We present the methodologies used to assess hazard, social vulnerability, and risk at the scale of CDMX and several examples of the studies and maps that constitute the RAGIS. We also include an electronic supplement that shows the hazard, vulnerability, and risk maps in PDF format generated or updated during this research (Online Resource 1). Although maps at the CDMX level is a small scale for the development of proper civil protection actions, the GIS maps will allow local authorities to intervene at the dwelling and neighborhood level. On the other hand, our database includes information about the 
footprint of buildings, density of population and housing, critical infrastructure as hospitals and schools of CDMX as well as the location of gas station, main markets, among other types of infrastructures (see Online Resource 1).

\section{Development of hazard reduction efforts in Mexico City and the Risk Atlas}

After the destructive earthquake of September 19, $1985\left(M_{w}\right.$ 8.1) (UNAM Seismology Group 1986), the Mexican authorities promoted various initiatives to build a nation-wide civil protection system to prevent disasters caused by natural phenomena and anthropogenic activity. Important early contributions were the creation of the National Civil Protection System (SINAPROC) in 1986 and the Mexican National Center for Disaster Prevention (CENAPRED). Also, the installation of civil protection offices was mandated at all levels of government.

An additional response was the development of the Seismic Early Warning System in 1989. Given the location of the city, large earthquakes in the subduction zone allow approximately $60 \mathrm{~s}$ of warning before the arrival of damaging seismic waves (EspinosaAranda et al. 1995; Suárez et al. 2009, 2018). Although these initiatives have achieved considerable progress, the local authorities recognized the need to continue improving disaster risk management based on preventive actions. As part of these efforts, the Secretariat of Education, Science, Technology, and Innovation (SECTEI) of the Mexico City government funded the present project to develop the RA-GIS. In this first phase, the main purpose is to identify the levels of hazard associated with earthquakes, volcanic eruptions, floods, landslides, forest fires, and land subsidence. Social vulnerability is also evaluated to estimate the risk posed by these natural hazards.

\section{Earthquake hazard}

Mexico has a long history of destructive earthquakes originating in the subduction zone (García-Acosta and Suárez 1996). Although the September 19, $1985\left(M_{w} 8.1\right)$, earthquake was located $\sim 350 \mathrm{~km}$ away from CDMX, the city suffered considerable damage and loss of life (Aguilar et al. 1989; Rosenblueth and Meli 1986; UNAM Seismology Group 1986; Stone et al. 1987). The city is also vulnerable to earthquakes located beneath the continent that reflect the deformation of the subducted Cocos plate. The more recent example occurred on September 19, 2017, when an intraplate earthquake $M_{w} 7.1$ was strongly felt by several communities in Mexico including CDMX. Its epicenter was located $150 \mathrm{~km}$ from the city at a depth of $55 \mathrm{~km}$. In Mexico City, more than 40 buildings collapsed, and 370 people perished.

An additional source of seismic hazard is represented by the crustal faults located on the Trans-Mexican Volcanic Belt (TMVB). Two large crustal earthquakes took place in the TMVB in the early twentieth century: the Acambay earthquake of November $19,1912\left(M_{w}\right.$ 6.9) (Urbina and Camacho 1913), and the Xalapa event of January 4, 1920 ( $\left.M_{w} 6.4\right)$ (Flores and Camacho 1922; Suárez and Novelo-Casanova 2018). Historical records also show a large number of crustal earthquakes in the TMVB in the last 450 years of written history (Suárez et al. 2019). 


\subsection{Seismic micro-zonation}

The CDMX building code classifies the local soil conditions into three seismic zones (Gobierno del Distrito Federal 2004): Zone I (hill zone) constituted mainly of basaltic and rhyolitic lava and compact pyroclastic flows; Zone II (transition zone) composed of sands and pyroclastic material from the surrounding volcanic deposits; Zone III (lakebed zone) composed of silt and volcanic clay sediments with a very high water content that suffer large ground amplification with passing seismic waves (Ordaz and Singh 1992; Lermo and Chávez-García 1994). Zone III is subdivided further into three zones. The stark contrasts of the geotechnical conditions of the soil in CDMX show that microzonation based on the natural period of the ground is an essential element in the evaluation of seismic hazard and in the design of building codes and regulations.

The spatial seismic response of the CDMX's subsoil was estimated using the spectral ratio technique developed by Nakamura (1989). It is considered that this spectral technique gives an approximation of the soil's transfer function, its amplification, and the natural period of vibration (Bard 1999). We used the following data: (a) new measurements made in 75 sites (Fig. 1); (b) records from 84 sites, previously obtained by different authors; and (c) recordings from 53 stations of the Accelerographic Network of Mexico City (RACM), operated by the Instrumentation Center and Seismic Recording (CIRES; Centro de Instrumentación y Registro Sísmico, in Spanish). These 212 measurements were interpolated using a thin plate spline (Duchon 1977) to outline the spatial distribution of the dominant periods of the soil in Mexico City (Fig. 1).

\subsection{Evaluation of seismic hazard}

Seismic hazard in CDMX was estimated for the return periods prescribed by CENAPRED of 20, 125, 250, and 475 years. The methodology considers the following steps (Jaimes and Niño 2017): (a) characterization of the different seismic sources potentially affecting CDMX (subduction, intraslab, and crustal); (b) use of appropriate ground motion models depending on the types of earthquakes (Abrahamson and Silva 1997; Jaimes et al. 2006, 2015; Jaimes and García-Soto 2020); (c) convolution of the response spectral ratios (Rosenblueth and Arciniega 1992) with the ground motion predictions; and (d) probability estimation of shaking intensity for the different return periods.

There is a univocal correlation between the thickness of the soft and water-saturated clays and the areas where the probability of high peak ground acceleration is observed. Areas in the central part of the ancient lakes are more heavily impacted by soil amplification. The estimated PGA values in the lakebed zone (Zone III) vary from a possible maximum $0.09 \mathrm{~g}$ for a return period of 20 years (Fig. 2a) up to $0.53 \mathrm{~g}$ for 475 years (Fig. 2d). These areas are concentrated in municipalities located in the central, southern, and eastern zones of the city (Fig. 2). 


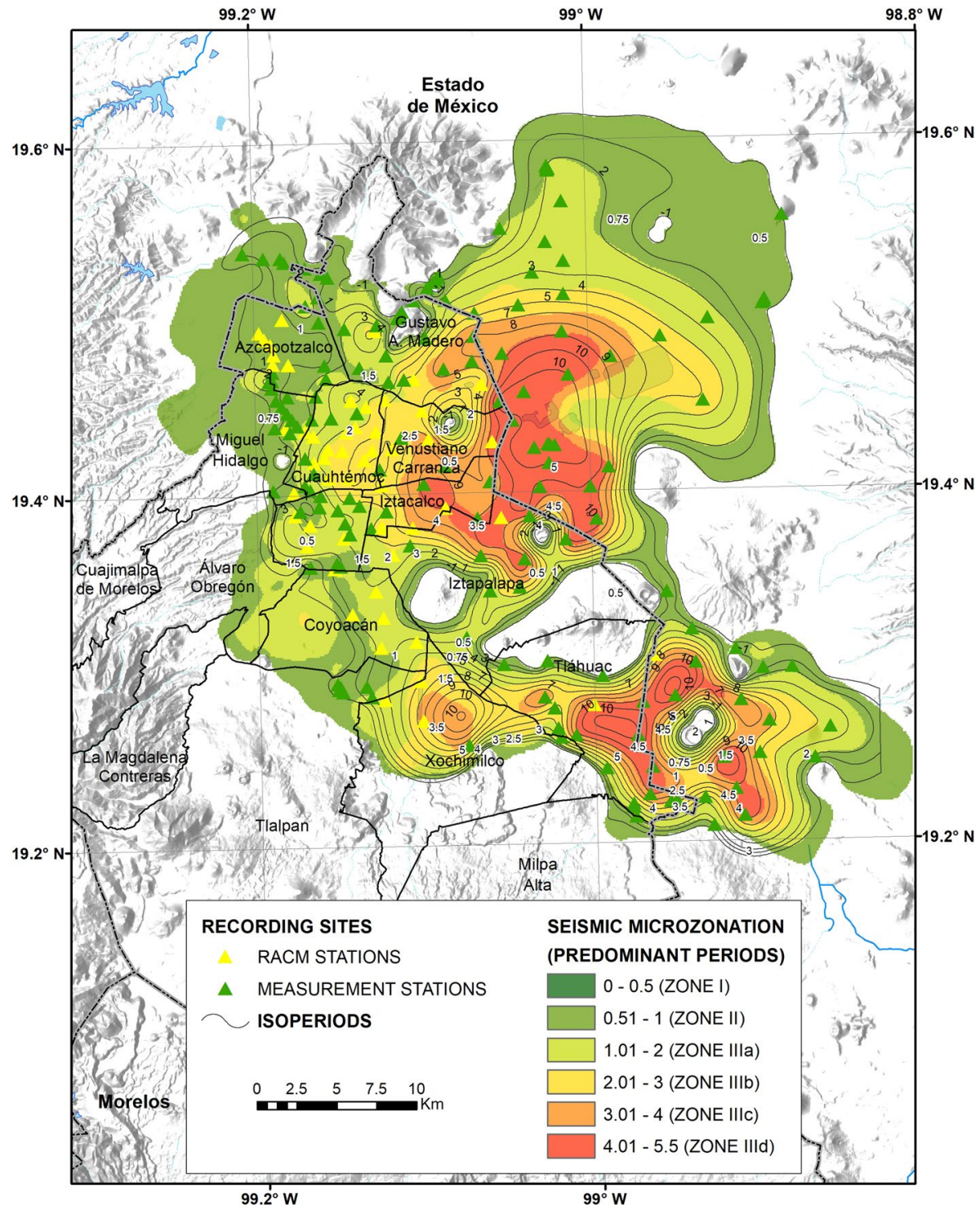

Fig. 1 Seismic micro-zonation of CDMX. Recording sites data of the Accelerographic Network of Mexico City (RACM) and stations' locations of new measurements indicated by yellow and green triangles, respectively

\section{Volcanic hazard in Mexico City}

\subsection{Eruption of a new volcano in the Younger Chichinautzin Monogenetic Field}

CDMX lies in the Trans-Mexican Volcanic Belt, an active Miocene to recent geological structure that spans central Mexico from the Pacific Ocean to the Gulf of Mexico (e.g., Ferrari et al. 2012). Unlike most volcanic arcs associated with subduction processes, 


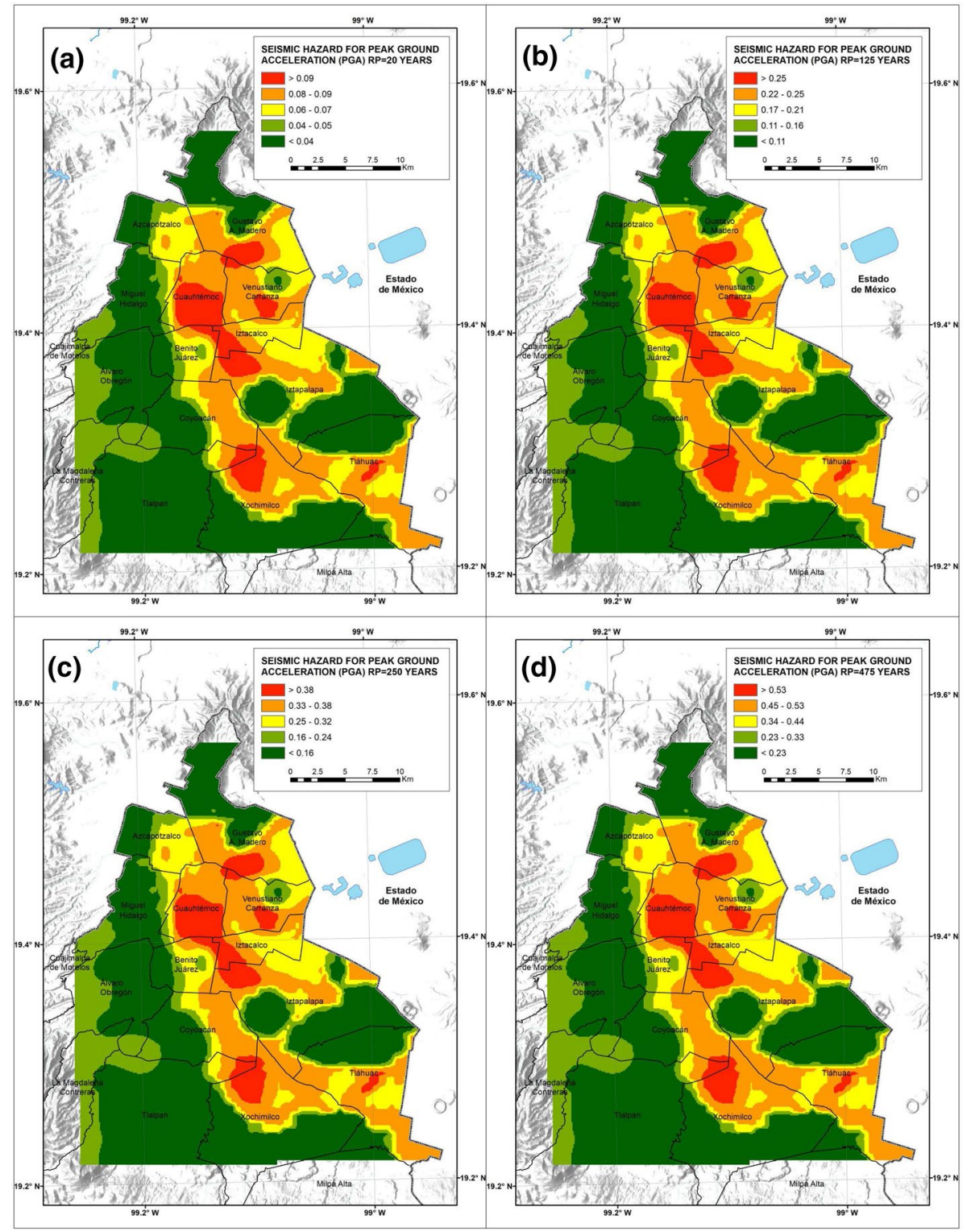

Fig. 2 Seismic hazard for peak ground acceleration (PGA) (g) for return periods of 20, 125, 150, and 475 years

the TMVB is oblique and not parallel to the trench where the Cocos and Rivera plates subduct beneath North America (Pardo and Suárez 1995). In this geological context, the CDMX is exposed to hazards presented by the surrounding volcanic structures.

One of these volcanic hazards stems from the Younger Chichinautzin Monogenetic Field (YCMF). This is a volcanic structure to the south of CDMX that is of particular interest due to its very young age and its potential impact on the city. Historical eruptions of 
the YCMF occurred at a time when the region was sparsely inhabited (Martin-Del Pozzo 1982; Córdoba et al. 1994; Martin-Del Pozzo et al. 1997). The lava flows covered an area of $70 \mathrm{~km}^{2}$ in southern CDMX burying the Cuicuilco civilization (Martin-Del Pozzo et al. 1997; Siebe 2000). Later, the Chichinautzin volcano erupted in 1835 BP covering a very large area of southern CDMX (Martin-Del Pozzo et al. 1997). Clearly, a new eruption in this region would have devastating consequences for the population and infrastructure of CDMX. To extend the existing studies of volcanic hazard in CDMX, we incorporated the recent work of Nieto-Torres and Martin-Del Pozzo (2019) and Nieto-Torres (2020), who estimated probabilistically the hazard associated with the eruption of a new volcano in the YCMF.

The volcanic activity of the YCMF was analyzed to probabilistically forecast future eruptions, assuming that this potential activity would follow a similar pattern in time as past volcanic eruptions. To this end, the monogenetic volcanoes of the YCMF were dated based on morphometric analysis (Wood 1980; Martin-Del Pozzo 1982; Hooper 1995). Wood (1980) proposed that the rate between the volcano's height $(H)$ and width $(W)$ is a rough indicator of the volcano's age. Thus, $H / W$ is higher for relatively young volcanoes than for older ones. This rate is called the volcano youth index $\left(I_{j}\right) . I_{j}$ were measured from multispectral images, topographic maps, digital elevation model (DEM), and fieldwork in the area. Nieto-Torres (2020) and Nieto-Torres and Martín- Del Pozzo (2019) used the ages of the volcanic edifices to determine a probability function for future eruptions of the YCMF in a $5 \times 5 \mathrm{~km}$ grid.

Based on a Grid Probability Analysis (Song et al. 2013), three areas (A, B, C) located close to the volcanoes with the most recent eruption history were identified to have a high probability of generating a new volcano in the YCMF (Fig. 3a). The results of the analysis

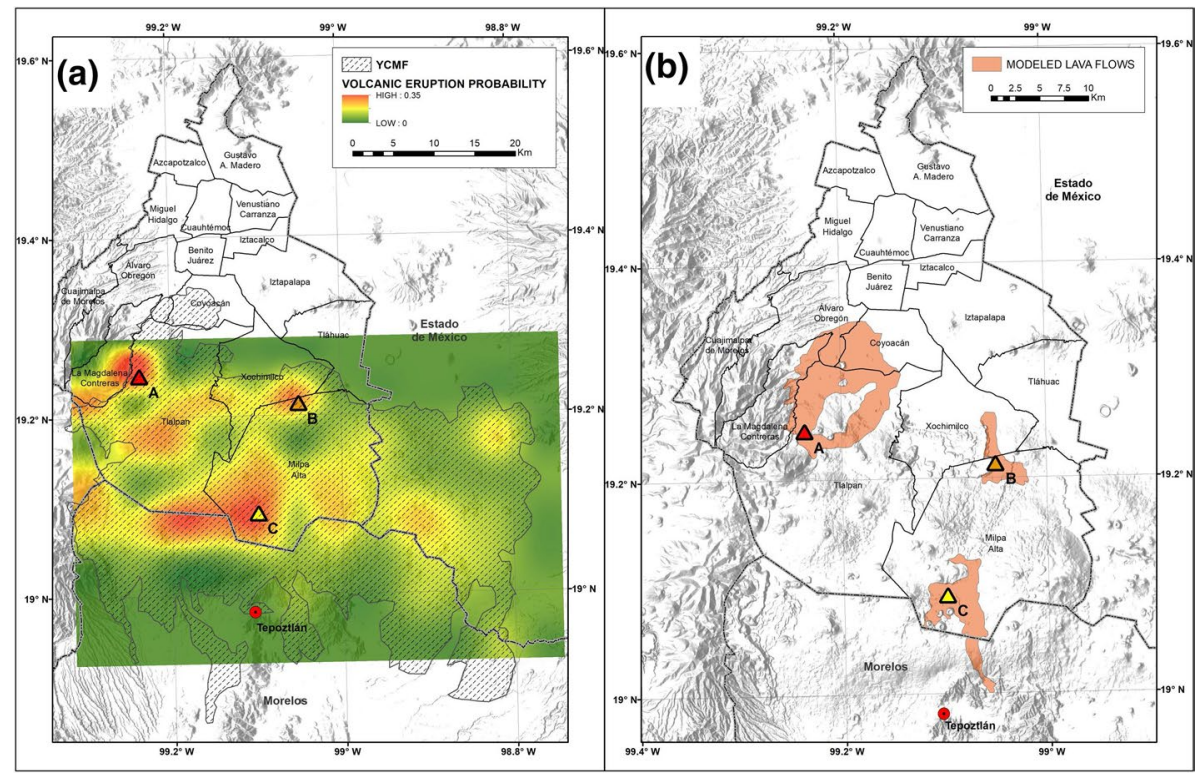

Fig. 3 a Zones A, B, and C indicate the more probable sites where a new volcano could erupt in the Younger Chichinautzin Monogenetic Field (YCMF). The spatial probability of hosting a future eruption in the YCMF is also indicated; b expected lava flows scenarios for zones A, B, and C (see text). From NietoTorres and Martin-Del Pozzo (2019) and Nieto-Torres (2020) 
show that there is 0.99 probability that a new eruption could take place in a 2000 -year window for the whole YCMF. This value agrees with the observation of Siebe et al. (2004) who suggest that eruptions in the YCMF have recurrence rates of $\sim 1700$ years. The hazard posed by this field of monogenetic volcanoes is highlighted by the fact that the last eruption took place 1670-2030 years BP.

Lava flows from each of these $\mathrm{A}, \mathrm{B}$, and $\mathrm{C}$ volcanic zones were modeled to estimate their potential thickness and areal span (Nieto-Torres 2020). This modeling was performed using the Etna Lava (Damiani et al. 2006) and the Q-LAVHA models (Mossoux et al. 2016) (Fig. 3b). Eruption in Zone A shows a scenario that would impact deep into Mexico City resulting with 5 -m-thick fluid lavas, extending for $12 \mathrm{~km}$; this scenario is to past volcanic activity of Xitle volcano (Nieto Torres and Martin-Del Pozzo 2019). In Zone B, viscous lavas with a thickness of about $150 \mathrm{~m}$ and a distance range of $5 \mathrm{~km}$ were modeled, considering that the eruption would be as those from the neighboring Xicomulco volcano (Nieto-Torres 2020). In the expected scenarios for Zone C, eruptions would produce fluid lava flows with thickness on the order of $3 \mathrm{~m}$ and travel distances in the range of $15 \mathrm{~km}$ (Fig. 3b) (Nieto-Torres 2020).

Nieto-Torres (2020) also modeled the spatial distribution of ashfall for volcanic eruptions in zones A and C using the software Tephra (Courtland et al. 2012). Ashfall for an eruption in region $\mathrm{B}$ was not considered because in this area previous volcanic activity consisted mainly of lava effusion. Nieto-Torres (2020) ashfall scenarios would result in many exposed elements in CDMX (population, houses, and critical infrastructure). Also, about $27 \mathrm{~km}^{2}$ of agricultural and $23 \mathrm{~km}^{2}$ of forested areas would be impacted. Primary communication routes in CDMX would be exposed and could delay the delivery of materials and medical supplies, as well as the operation of basic services such as banks, gas stations, hotels, self-service stores, airports, etc. Additionally, these ash deposits would cause health and sanitary effects.

\section{Subsidence of the ground in CDMX}

Land subsidence is generally related to the consolidation of fine-grained materials in response to the extraction of fluids from underground compressible soil (Galloway and Burbey 2011; Herrera et al. 2021). Subsidence in CDMX is a major hazard due to the intensive water extraction rates from its underlying lacustrine, water-saturated sediments. Ground subsidence was first reported in CDMX in the early twentieth century. It is estimated that parts of CDMX have subsided as much as nine meters since the mid nineteenth century (Gayol 1925; Carrillo 1948).

In the past decade, subsidence of the city has been studied with modern geodetic techniques (Cabral-Cano et al. 2008; López-Quiroz et al. 2009; Osmanoglu et al. 2011; Chaussard et al. 2014; Du et al. 2019; Fernández-Torres et al. 2020; Solano-Rojas et al. 2020; Cigna and Tapete 2021). In this study, subsidence in CDMX was analyzed using 125 images recorded between November 2014 and October 2017 by the C-band SAR (Synthetic Aperture Radar) instrument onboard the Sentinel 1-A and B in Interferometric Wide Swath, descending mode (Fig. 4a). The dataset was processed using the ISCE software (Rosen et al. 2012) to generate interferometric pairs and SBAS time-series using the program MintPy (Yunjun et al. 2019). Following Osmanoglu et al. (2011), the former GPS site UCHI was used as the reference point along with stations UTUL and UFXN that are part of the TLALOC Net GPS network (Cabral-Cano et al. 2008). 


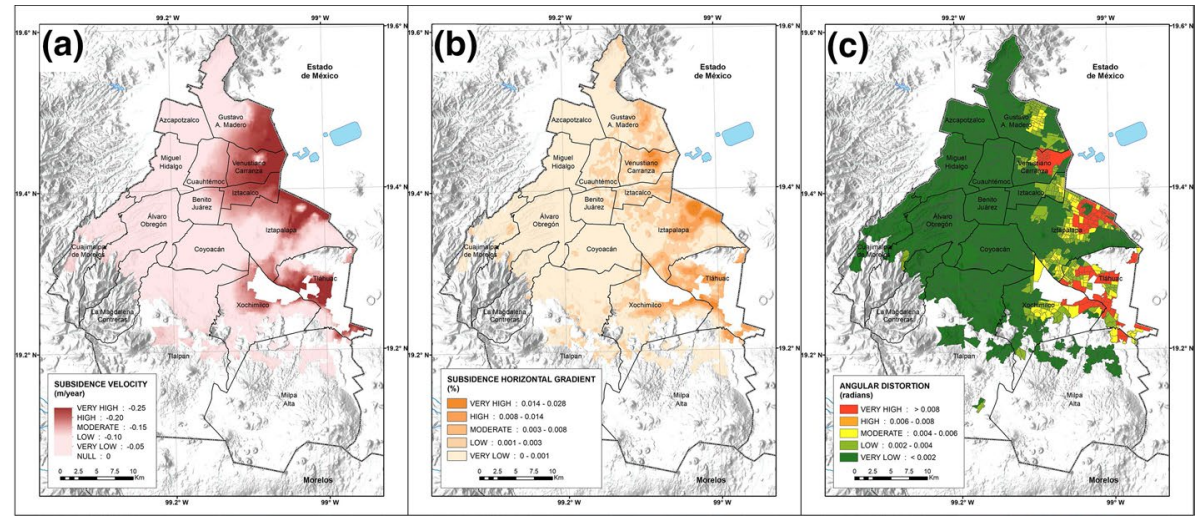

Fig. 4 Spatial distribution of: a subsidence rate; b horizontal subsidence gradient; $\mathbf{c}$ angular distortion for the CDMX

The zones with very high subsidence rates with more than $25 \mathrm{~cm} / \mathrm{yr}$ (line of sight) are concentrated toward the northeast, southeast, and east of CDMX (Fig. 4a). In some cases, these large subsidence rates result in soil fractures.

\subsection{Horizontal subsidence gradient}

A horizontal subsidence gradient (HSG) was also determined for detecting areas with the potential to generate fractures and faults due to differential subsidence (Cabral-Cano et al. 2008, 2015). Our results are presented within the spatial framework of the Basic Geo-statistical Areas (AGEB). An AGEB is defined by the Mexican Institute of Geography and Statistics (INEGI) as a basic geographic area where a group of city blocks (1-50) are well delimited by streets and avenues or any other easily identified urban feature where the land use is mainly for housing, industry, commerce, and other urban services.

Based on the AGEB spatial distribution, three regions with large HSG (0.014-0.024\%) were identified mainly to the east of CDMX (Fig. 4b). These high-gradient zones are located on the abrupt transition between lacustrine sediments undergoing subsidence and the stable volcanic rocks (Cabral-Cano et al. 2008, 2015). In these areas, considerable differences in relative vertical motion develop over short distances, resulting in high horizontal strain and surface faulting that eventually fracture buildings (Burland et al. 2004).

\subsection{Angular distortion}

Angular distortion $(\beta)$ is the ratio of the differential subsidence $(\delta)$ between two surface points located at a distance $(L)$ (Ricceri and Soranzo 1985):

$$
\beta=\delta / L
$$

Skempton and Macdonald (1956) proposed expected levels of damage due to angular distortion variations based on studies throughout the world (the UK, Austria, Brazil, the USA, and Mexico) (Table 1). These values are now used as a reference for construction design (Meyerhof 1956; Bjerrum 1963; Wahls 1981). 
Table 1 Values of angular distortion and their impact to structures (Skempton and Macdonald 1956)

\begin{tabular}{ll}
\hline $\begin{array}{l}\text { Angular distor- } \\
\text { tion (radians) }\end{array}$ & Impact to structures \\
\hline 0.0066 & $\begin{array}{l}\text { Cracking panels in traditional frame buildings or on } \\
\text { the walls of load-walled structures }\end{array}$ \\
0.0033 & $\begin{array}{l}\text { Structural damage to columns and beams } \\
0.0020\end{array}$ \\
0.0010 & $\begin{array}{l}\text { Design limit to prevent cracking } \\
\text { Design limit to avoid any damage due to subsidence }\end{array}$
\end{tabular}

For a clear representation of the angular distortion worst-case scenario, we assigned its maximum value to each of CDMX's AGEBs (Fig. 4c). As expected, the higher angular distortion rates ( $>0.008$ radians) are observed in the municipalities located to east of the city, near the boundary between the soft soils and the volcanic terrains (Fig. 4c), damaging structures located in this region (Table 1).

\section{Floods}

Despite the intensive and ambitious engineering projects undertaken to drain CDMX during periods of heavy rain, the closed nature of the basin coupled to the continued land subsidence induced by water extraction of the subsoil creates a permanent threat of flooding in several parts of the city.

\subsection{Return period and volume}

To estimate the return period of floods, we analyzed the hydrological characteristics of the greater Metropolitan Zone of the Basin of Mexico (MZBM) that extends beyond the political boundaries of CDMX and was geographically divided into 250 regions "tributary stream areas" that were determined considering the local topography, land use, and drainage. The precipitation data from pluviometric stations were obtained from the Mexican National Water Commission for the period 1920 to 2015 (http://clicom-mex.cicese.mx).

The analysis was restricted to pluviometric records comprising twenty or more years and with complete daily rain datasets from June to October, the rain season in Mexico City. For each selected station, we obtained the maximum rainfall per year and a frequency analysis was performed using the software $A x$ developed by CENAPRED that allows the estimation of probability functions for temporal series (Jimenez 1996).

The effective rainfall was obtained multiplying the rainfall sheet for a specific return period by the runoff coefficient of each tributary area considering the type of soil and land use (Goel 2011):

$$
h_{e i}^{T r}=h_{i}^{T r} C_{e i}
$$

where:

$i=1,2,3, \ldots, 250$ : identifies the tributary area.

$h_{i}^{T r}$ : rainfall sheet for the tributary area I and return period $T_{\mathrm{r}}$

$C_{e i}$ : runoff coefficient for tributary area $i$.

$h_{e i}^{T r}$ : effective rainfall sheet $(\mathrm{m})$ for the tributary area $i$ with return period $T r$. 
The flood volume for each tributary area $\left(V_{i n d i}^{T r}\right)$ was obtained by multiplying the effective rainfall sheet for a determined return period $\left(h_{e}^{T r}\right)$ by the area of the tributary area $\left(A_{i}\right)$ (Goel 2011):

$$
V_{\text {ind }_{i}}^{T r}=A_{i} h_{e i}^{T r}
$$

Assuming that the flood volume in each tributary area is concentrated in zones of low topographic elevation in a hemisphere, the water volume was estimated from the following equation:

$$
V_{\mathrm{inu}}=\frac{\pi h^{2}}{3}(3 r-h)
$$

where:

$V_{\text {inu }}$ : flood's volume $\left(\mathrm{m}^{3}\right)$.

$h$ : flood's height $(\mathrm{m})$

$r$ : hemisphere's radius $(\mathrm{m})$.

To estimate the water mirror's area $(A)$ and the flood's radius $(a)$, we used the following equations:

$$
\begin{gathered}
A=\pi a^{2} \\
a^{2}=2 r h-h^{2}
\end{gathered}
$$

\subsection{Flood area}

The flood areas were estimated using the following data:

(a) The water volume database obtained following the procedures described above for each tributary area.

(b) The vector data of each tributary area.

(c) The DEM of CDMX.

With this information, the procedure to estimate the flood area is as follows:

Step 1: Flood heights were calculated considering the water volumes resulting from the different return periods. Using the DEM of CDMX, a 3D elevation model was determined with topographic contours every $0.10 \mathrm{~m}$. Based on these data and using the "Polygon Volume" function of ArcGis10.3, we computed the water volume for a specific tributary area. These procedures were repeated until the theoretical volume (described above) was reached for the return periods considered. The topographic contours that contain the estimated volume provide the most probable zones that could potentially be flooded in the MZMV.

Step 2. With the tool Extract by Mask of ArcGis10.3, the raster of the flooding area was extracted, and a new classification was obtained considering five flood heights where less than $20 \mathrm{~cm}$ and greater than $80 \mathrm{~cm}$ correspond to very-low and very-high hazard levels, respectively (Table 2).

Following these procedures, floods in CDMX were estimated for return periods of 2, 5, 10, 50, and 100 years, as established by CENAPRED (Fig. 5). Most of the potential flood 
Table 2 Flood hazard according to flood's height

\begin{tabular}{ll}
\hline Hazard level & Flood height $(\mathrm{cm})$ \\
\hline Very low & $<20$ \\
Low & $20-40$ \\
Moderate & $40-60$ \\
High & $60-80$ \\
Very high & $>80$
\end{tabular}
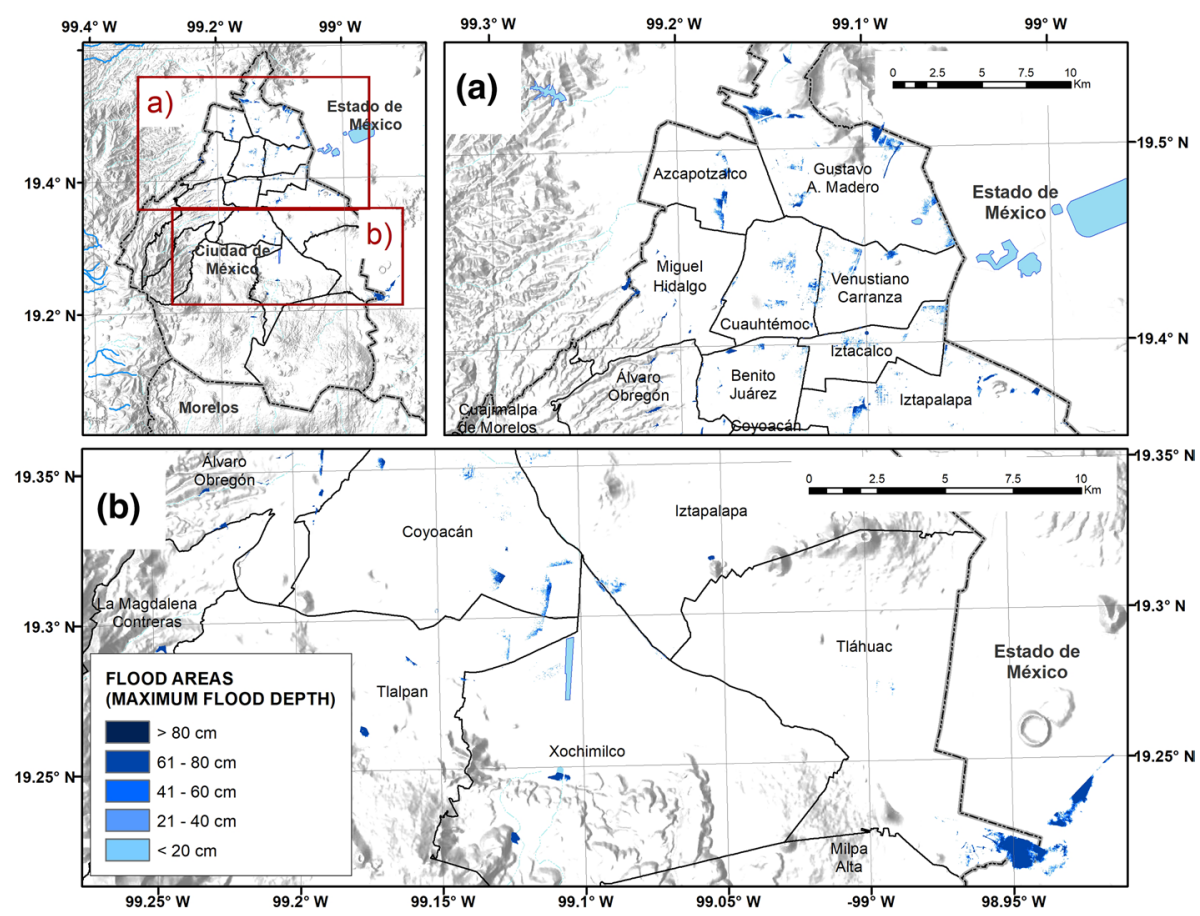

Fig. 5 Flood hazard estimation for a return period of 10 years in the CDMX

areas in MZMV are concentrated in the central and in the northern part of its territory. This is coincident with the flood inventory for the period 1920-2017 compiled as part of this project (Online Resource 1).

The explosive urban growth has dramatically enlarged the impervious zone in Mexico City and increased the volume of rainwater that must be drained out of the basin. In many cases, the local drainage network is insufficient for this task. This situation leads to recurrent large flooding causing serious urban damage in CDMX. 


\section{Forest fires}

The Mexican National Forest Commission (CONAFOR) installed in 1999 an early warning system (EWS) to alert for forest fires. This EWS is designed to evaluate and reduce the hazard represented by these fires. It is based on measurements of temperature, relative humidity, precipitation, and wind velocity. Using an index based on the initial propagation velocity and available fuel, the CONAFOR's EWS provides a meteorological index for fire hazard (http://forestales.ujed.mx/incendios/inicio/evolucion_del_peligro.php\#).

In this project, the forest fire EWS was extended to forecast fires in the long term with the purpose of supporting local authorities in the development of preventive actions to reduce risk to the exposed population. We used satellite data from the NASA's Fire Information for Resource Management System (FIRMS) (https://firms.modaps.eosdis.nasa.gov/ active_fire/\#firms-shapefile) for the period 2000 to 2019. This database provides fire hotspots locations, including coordinates, temperature, brightness, and resolution.

Fire hazard estimations are based on the Clustering Machine Learning tool to group temperature and brightness in clusters (Buduma and Locascio 2017). For our calculations, we used the boasted trees algorithm to analyze cluster data (Maloof 2005). This algorithm identifies groups of similar objects and establishes the pattern distribution of large datasets. Decision trees are machine-learning tools where each tree is dependent on previous trees. The algorithm "learns" continuously by fitting the residual of preceding trees.

The probability of fire occurrence was estimated for the rain and dry seasons for the next five years for the eastern, and southern regions of CDMX (Fig. 6a, 6b). During the rainy season (May-November), there is moderate probability (41-60\%) of forest fires south of CDMX for the next five years (Fig. 6a). However, during the dry season (December-April), southern CDMX has high probability of forest fires $(>81 \%)$ in the forests of the Tlalpan, Xochimilco, and Tláhuac municipalities (Fig. 6b).

Using the Machine Learning tool, we also forecast the number of expected forest fires up to the year 2028 (Fig. 6c). We estimated that during the year 2025, there is a high probability that 1400 forest fires occur in CDMX (Fig. 6c). This number is higher than the number of previous forest fires during the 1970-2020 periods. This forecast is based on the decadal periodicity of wildfires in CDMX. Our model predicted that in 2020 a new highforest fire season initiated and that it will reach its peak around 2025.

\section{Landslide hazards in Mexico City}

Several municipalities of CDMX are located on the volcanic deposits that form the Las Cruces, Guadalupe, and Chichinautzin (LCGC) ridges to the west and southern areas of the city. These volcanic edifices constitute the limits of the lacustrine basin. Besides the natural instability associated with the steep slopes of the terrain, land alteration due to urban growth and erosion has increased the susceptibility for the occurrence of landslides and rock falls in these regions. In addition, several communities are irregular settlements, increasing the exposure to landslides.

As a first step to estimate landslide susceptibility, an inventory was compiled for the period 1972 to 2018. The database was constructed from local newspapers reports, the Internet platform Desinventar (https://www.desinventar.org), and information provided by municipalities of CDMX. Desinventar is a tool containing data of human and material 

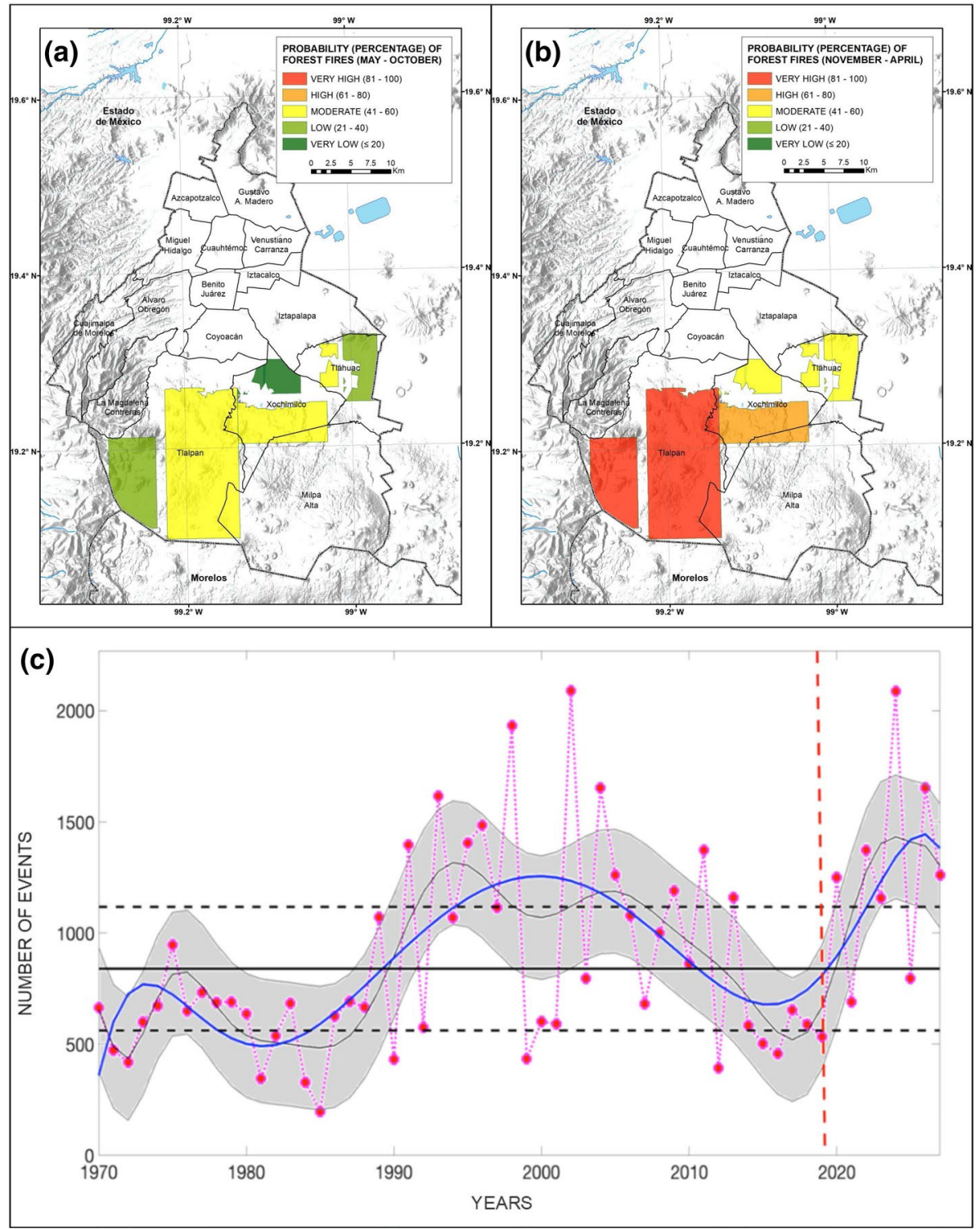

Fig. 6 a Probability of forest fires occurrence in CDMX during the rainy season for the following five years (2021-2025); b the same as a for the dry season; c forest fire forecast from 2020 to 2028. Red dots are the annual number of forest fires reported by the Mexican National Forest Commission until 2020. The blue line approximates the data's tendency. The vertical red dashed line separates the historical from the forecast data. The horizontal solid and dashed lines indicate the mean and standard deviation, respectively. The shadowed area outlines the $95 \%$ confidence interval

losses, damages, disasters, and events that have impacted different countries in Latin American and the Caribbean. Our landslide and rock fall inventory included the location, date of occurrence, size, typology, and damage. However, all this information was not available for some events. 


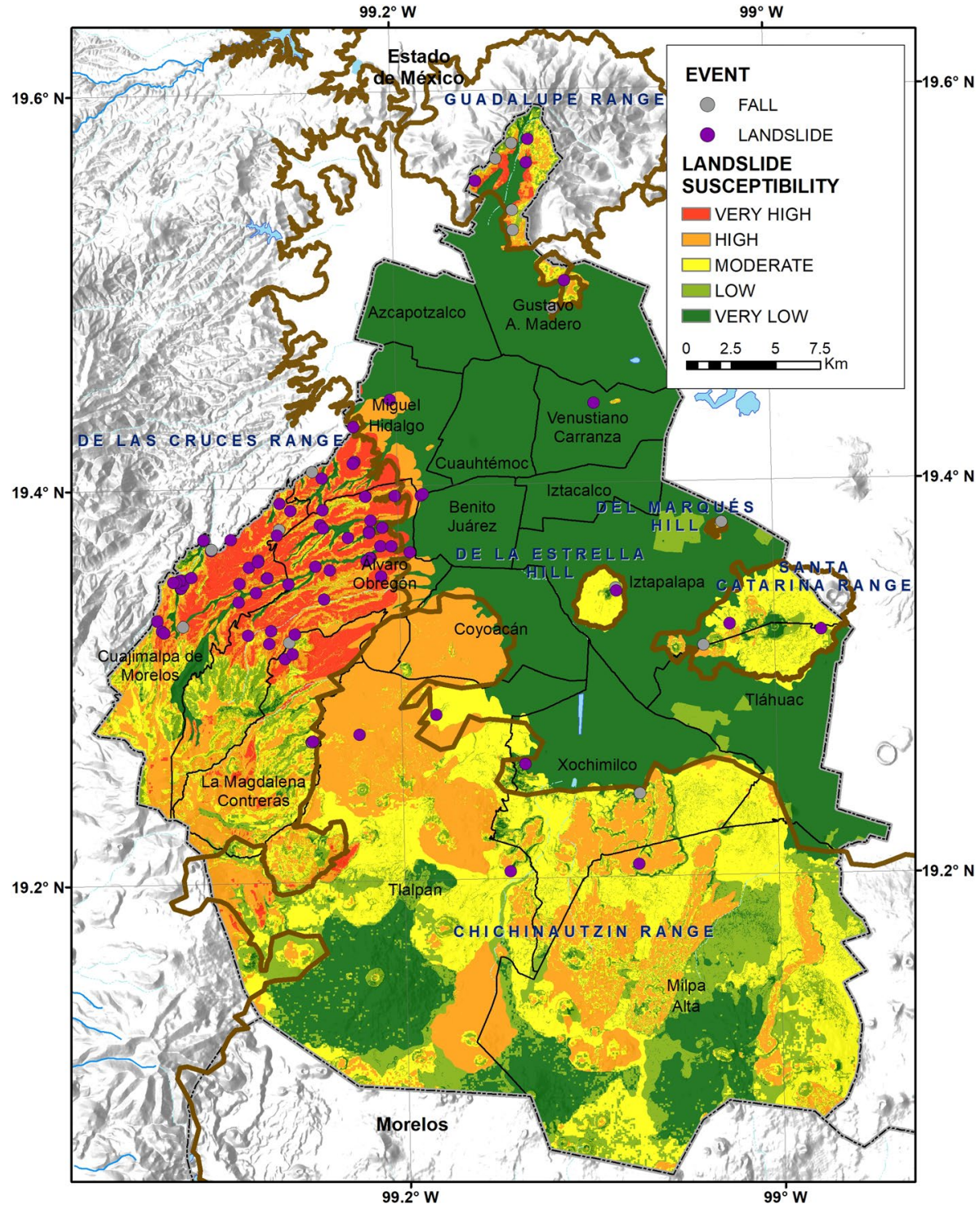

Fig. 7 Inventory of landslides and rock falls (purple and gray solid circles) and spatial distribution of landslide susceptibility

We recorded more than 100 landslides in the inventory and as expected, most of them occurred during the rainy season, from May to November. Many of these events are concentrated in the western part of CDMX. However, some are also reported around the hills in the eastern part of the city in the LCGC and the Santa Catarina ranges (Fig. 7).

The landslide susceptibility estimation also included fieldwork, interpretation of satellite images, analysis of samples in laboratory, and municipal inventories. We used a 5-m resolution DEM to generate the hypsometric and slope maps. Using the univariate 
Table 3 Weights for parameters used to estimate landslide susceptibility

\begin{tabular}{ll}
\hline Parameter & Weight \\
\hline Geology & 0.60 \\
Slope & 0.20 \\
Relative height & 0.10 \\
Land use and vegetation & 0.10 \\
Total & 1.00 \\
\hline
\end{tabular}

statistical method (Denis 2020), and after testing different weights to identify those with less uncertainty for different scenarios, we weighed each of these parameters according to their assumed importance for a landslide to occur. We considered geology as the principal parameter that conditions the characteristics of landslide susceptibility, followed by the slope, relative height, land use, and type of vegetation (Table 3). Also, each variable within each parameter was weighed considering relative values from 1 to 5 to indicate how much that variable increases the landslide susceptibility with 1: very-low and 5: very-high (Table 4). To geology, values of 5 were given to very altered rocks with fractures and faults of andesite, dacite, and lahar deposits as well as pumice flow, volcanic ash, and alluvial deposits. To slope $>60^{\circ}$, relative heights $>100 \mathrm{~m}$, and human settlements parameters, we also assigned values of 5 (Table 4). The results were classified in five categories of susceptibility (Fig. 7): very low, low, moderate, high, and very high.

The results of this study are intended to support the development of preventive actions and land use policies designed to avoid the catastrophes and loss of life associated with landslides and rock falls in the past 50 years (García-Palomo 2006).

\section{Social vulnerability of CDMX}

Social vulnerability is an intrinsic characteristic of society that is independent of its exposure to natural and man-made hazards. However, social vulnerability is the most complicated component of risk to measure. This is because the concept is given varying interpretations and conceptual frameworks by different authors (Cutter et al. 2003; Rashed and Weeks 2003).

We consider thirteen indicators that reflect the social characteristics of the population, such as age, access to basic services (electricity, water, drainage, etc.), income, and educational level (Table 5). These indicators were obtained from the 2010 Mexican Census of Population and Housing (Instituto Nacional de Estadística, Geografía e Informática 2010; https://www.inegi.org.mx/programas/ccpv/2010/). We excepted housing's indicators, because this Census lacks information regarding the type of structure or dwelling. Each of the selected indicators was weighed using the Hierarchical Analytical Process (HAP) (Saaty 1980). Saaty (1987) pointed out that "The HAP is a general theory of measurement. It is used to derive ratio scales from both discrete and continuous paired comparisons. These comparisons may be taken from actual measurements or from a fundamental scale that reflects the relative strength of preferences and feelings." The HAP was applied considering the opinion of experts from CENAPRED and from the authors of this work (Table 5). As a result of this methodology, the parameters that were given larger weights are population density, access to information, level of education, and availability of basic 
Table 4 Weights for the variables considered to estimate landslide susceptibility

Variable Weighting

\section{Geology}

Lake alluvial deposits

Basalt (Quaternary)

Andesite (Quaternary

Basaltic andesite (Quaternary)

Alluvial deposits (foothill)

Andesite

Basalt

Andesitic-basaltic (altered lavas)

Dacite

Basaltic andesite (cones)

Andesite (very altered and fractured rocks)

Basalt (Very altered and fractured rocks)

Basaltic andesite (very altered and fractured rocks)

Dacite (very altered and fractured rocks)

Basaltic andesite (very altered cones)

Basalt (very altered cones)

Lahar deposit

Pumice flow

Avalanche

Andesite (very altered rocks with fractures and faults)

Dacite (very altered rocks with fractures and faults)

Lahar deposit (very altered rocks with fractures and faults)

Pumice flow and volcanic ash

Alluvial deposits (slope)

Slope (degree)

$0^{\circ}-5^{\circ}$

$5^{\circ}-15^{\circ}$

$16^{\circ}-30^{\circ}$

$45^{\circ}-60^{\circ}$

$>60^{\circ}$

Relative Height ( $\mathrm{m}$ )

0-10

11-20

20-50

50-100

$>100$

Land use and vegetation

Body of water

Hydrophilic and halophilic

Tule

Oyamel forest

Sarcocaulous shrubland 
Table 4 (continued)

\begin{tabular}{lc}
\hline Variable & Weighting \\
\hline Halophile grassland & 3 \\
Induced grassland & 3 \\
Secondary shrub vegetation of oyamel forest & 3 \\
No apparent vegetation & 4 \\
Annual irrigation agriculture & 4 \\
Urban Zone & 4 \\
Human settlements & 5 \\
\hline
\end{tabular}

Very low: 1; low: 2 ; moderate: 3 ; high: 4 ; very high: 5

Table 5 Weights for indicators used to assess social vulnerability

\begin{tabular}{lll}
\hline Indicator & Description & Weighing $\left(w_{i}\right)$ \\
\hline $\mathrm{SV}_{1}$ & Health & 0.069 \\
& Percentage of population with access to public or private health services & 0.80 \\
$\mathrm{SV}_{2}$ & $\begin{array}{l}\text { Education and Knowledge } \\
\text { Percentage of illiteracy }\end{array}$ & \\
$\mathrm{SV}_{3}$ & Percentage of population between 6 and 14 years old that do not attend school & 0.065 \\
$\mathrm{SV}_{4}$ & Percentage of devices or technology for accessing information & 0.110 \\
$\mathrm{SV}_{5}$ & Level of education & 0.107 \\
$\mathrm{SV}_{6}$ & Housing & 0.117 \\
$\mathrm{SV}_{7}$ & Percentage of housing without basic services & 0.058 \\
$\mathrm{SV}_{8}$ & Percentage of houses with dirt floor & 0.087 \\
$\mathrm{SV}_{9}$ & Percentage of overcrowding (number of family members/ numbers of rooms) & 0.040 \\
$\mathrm{SV}_{10}$ & Employment & Percentage of economic dependency ratio \\
$\mathrm{SV}_{11}$ & Population density & 0.107 \\
$\mathrm{SV}_{12}$ & Percentage of indigenous-speaking population & \\
$\mathrm{SV}_{13}$ & Percentage of female-headed households & 0.055 \\
\hline
\end{tabular}

services (Table 5). To map the spatial distribution of the social vulnerability (SV) of CDMX, the social indicators were processed as follows:

1. For each AGEB in CDMX, we determined the proportional contribution of the following indicators: $S V_{1}, S V_{2} \ldots$ to $S V_{13}$ (Table 5).

2. $S V_{5}$ reflects the average of completed education years within each AGEB.

3. $S V_{10}$ reflects the population density, and it is estimated as the ratio of the number of inhabitants and the area of each AGEB.

4. $S V$ is then calculated using the following equation:

$$
S V=\sum_{i=1}^{13} S V_{i} * w_{\mathbf{i}}
$$




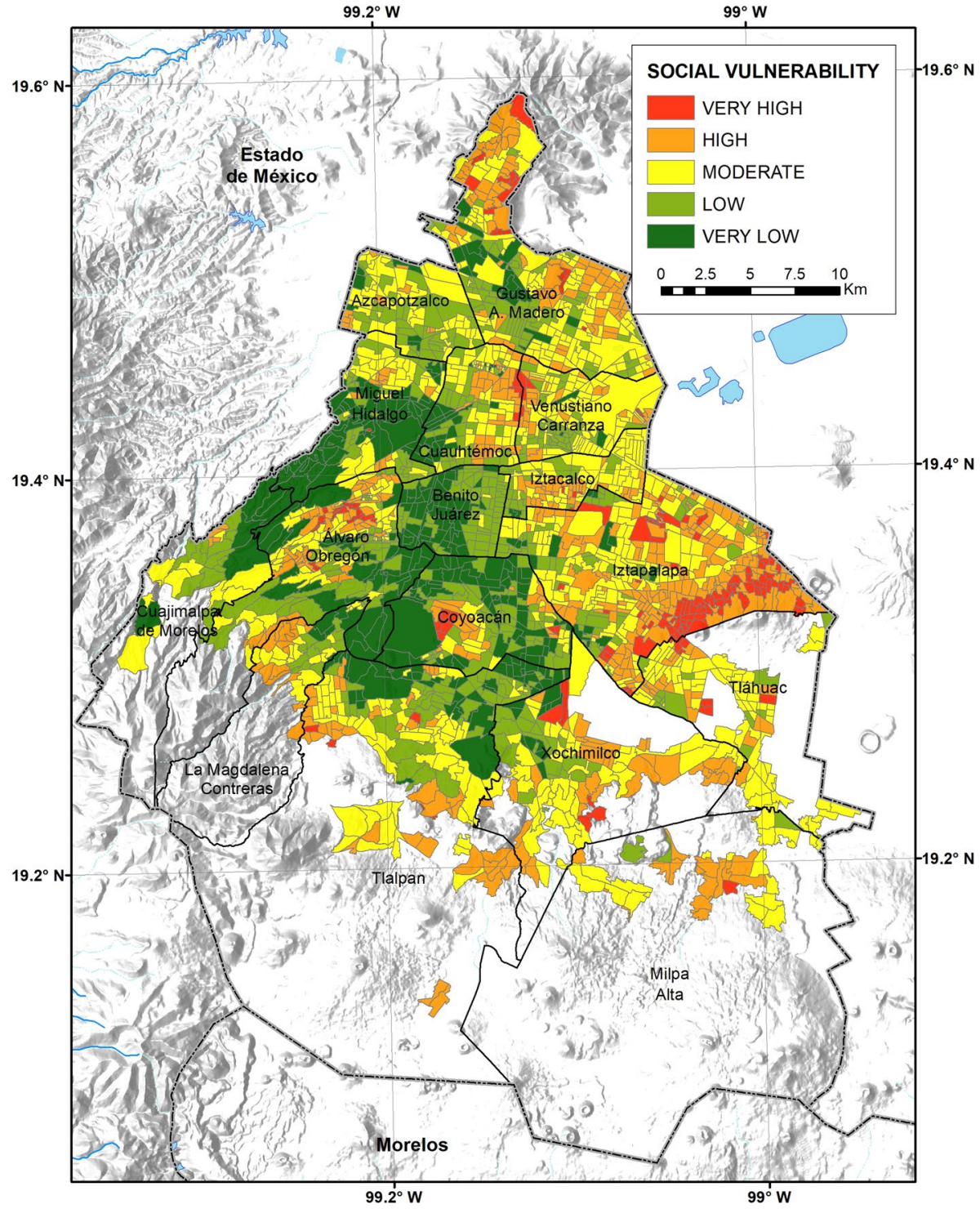

Fig. 8 Map with the spatial distribution of social vulnerability in CDMX obtained considering the variables of Table 5 and data processing as described in Sect. 9

where $w_{i}$ are the weights obtained applying the HAP methodology (Saaty 1987; Table 5). Using Eq. (7) the social vulnerability of CDMX was classified into five levels: very low, low, moderate, high, and very high by utilizing the Jenks Natural Breaks classification of the ArcGIS10.3 that reduces the deviation from the class mean (Fig. 8). Our results show that social vulnerability varies between moderate and very high in the north, northeast, east, and central regions of CDMX (Fig. 8). Unfortunately, more than half of the population of CDMX has a level of social vulnerability that varies between 
moderate and very high that may be closely tied to the average socioeconomic level of the population.

\section{Exposure}

Exposure refers to the people, communities, and their assets that are predisposed to a particular hazard. The RA-GIS contains GIS layers of the following exposed elements: population, population density, public schools (elementary, high school, college-university), hospitals, markets, fuel and radio stations, free connectivity sites (free internet places), and TV stations. We found a large fraction of the population and of critical infrastructure in CDMX exposed to the different hazards here analyzed (Online Resource 1).

\section{Social risk}

Risk measures the probability of damage considering the combination of three factors: hazard, vulnerability, and exposure (Crichton 1999; Cutter et al. 2003). According to the United Nations Disaster International Strategy for Disaster Reduction (2009), social risk is "The probability of possible losses (loss of human life, injury, disturbance in economic activities, goods deteriorated or destroyed, alterations of the environment) determined by a certain danger, under some circumstances of exposure and vulnerability" (UNISDR 2009).

In this work, risk is expressed using a qualitative spatial multi-criteria evaluation technique by superimposing the raster of the social vulnerability over individual hazard rasters. We consider that by using this method we are measuring the "likelihood of social risk." Vulnerability and hazard are classified into five categories, with values from 1 to 5. As a result, a meshing array reflects the likelihood of social risk for specific hazards. Under these considerations, the minimum and maximum values of risk are: 1 $(1 * 1)$ and $25(5 * 5)$. Risk is then classified in five intervals from very low to very high (Table 6) and its spatial distribution is obtained using a Kriging spatial interpolation method (Burrough and McDonnell 1998).

Following these procedures, large extensions in the northeast and east of CDMX show moderate to high levels of social risk due to subsidence (Fig. 9a). On the other hand, seismic social risk also varies from moderate to high in the central as well as the eastern and northeastern region of CDMX (Fig. 9b).

Table 6 Classification of risk

\begin{tabular}{ll}
\hline Level of risk & Score \\
\hline Very low & $1-5$ \\
Low & $6-10$ \\
Moderate & $11-15$ \\
High & $16-20$ \\
Very high & $21-25$ \\
\hline
\end{tabular}




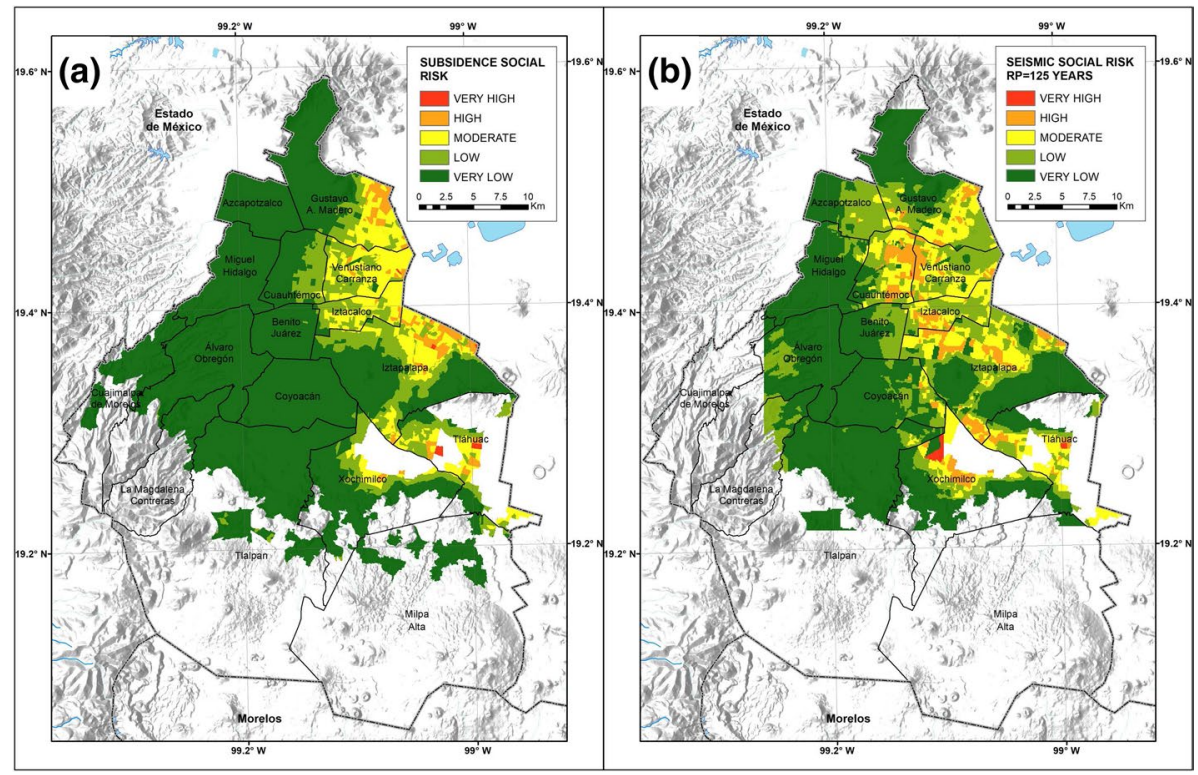

Fig. 9 Social risk in the CDMX for: a subsidence; and $\mathbf{b}$ an earthquake with a return period of 125 years

\section{Examples of seismic risk scenarios}

As an integral part of the Risk Atlas of CDMX, we developed eight seismic risk scenarios (see maps in Online Resource 1). Scenarios 1 and 2 correspond to the September 19, 2017, and September 17, 2017, earthquakes, respectively. Scenarios 7 and 8 reflect the potential damage expected from an earthquake similar to the Acambay earthquake $\left(M_{w}\right.$ 6.9) that took place on November 19, 1912, at distances of 80 and $40 \mathrm{~km}$ from CDMX (Online Resource 1). Details about the procedures and the results from these scenarios will be presented in subsequent publications.

\section{Retrospective}

In general, there are three phases to mitigate and manage risk: (1) assessment and analysis; (2) implementation of mitigation and preventive actions based on the knowledge of the spatial distribution of risk; (3) design of short- and long-term plans to reduce the social construction of risk (public policies, land-use planning, environmental restoration, etc.). The objective of this paper is to present a tool to assess the level and the spatial distribution of social risk to subsidence, floods, earthquakes, volcanic eruptions, forest fires, and landslides in CDMX. Our results are a contribution to the first phase of risk management by providing hard evidence to local authorities and citizens to develop preventive actions and mitigation procedures to reduce the impact of future disasters in CDMX.

The main functions of this tool are: 
- To provide decision and policy makers with appropriate risk information to strengthen their capacity to develop risk management strategies.

- To interactively view and retrieve different hazard, social vulnerability, and risk maps at the CDMX level.

- To view and retrieve the maps of exposed elements to the different hazards analyzed, including both, population, and infrastructure.

- Encourage the development of local case studies of social vulnerability and risk for specific hazards.

- Provide a catalyst for a holistic approach aimed at making CDMX a more resilient community.

Our findings also provide elements for the development of early warning systems. Also, our results point out areas where the relocation of population exposed to very high levels of natural hazards may be considered. Clearly, a complete analysis of the risk posed by manmade hazards (explosions, spills, etc.) and sanitary-ecological hazards (soil and air pollution, etc.) needs be considered in the future.

Supplementary Information The online version contains supplementary material available at https://doi. org/10.1007/s11069-021-05059-z.

Acknowledgements Our sincere gratitude to Aurora Hernández Hernández, Andrea Juárez Sánchez, Patricia Medina Andrade, Ana B. Ponce Pacheco, Alma R. Espinoza Jiménez, Uriel Martínez Ramírez, Guadalupe Hernández Bello, Paola A. Olmedo Velázquez, Omar Huerta Espinoza, Karla E. Escobar Mercado, Magdalena V. Hernández Luna, Diego E. López Maldonado, Nuria D. Vargas Huipe, Amalia E. Macías Rojas, Sabrina E. Espinosa Pacheco, Amayrani Martinez Mendoza, Daniel Ruiz Barón, Susana Rodríguez Padilla, Claudia B. López Venegas, Pamela I. Pedroza Rodríguez, Fernando García Yañez, Esteban Lugo Zavala, Jéssica Atilano Pablo, Heber A. Pacheco Silva, Karla P. Sánchez Albizar, Alma E. Macías Rojas, Sandra K. González Hernández, Brenda A. González Hernández, Mariana Sandoval García, Montserrat Luna Contreras, and Héctor Raúl Estévez Pérez for invaluable support for data acquisition, processing, storage and management, and for logistics coordination in the fieldworks. We thank the civil protection offices of the following CDMX municipalities: Álvaro Obregón, Azcapotzalco, Cuajimalpa, Cuauhtémoc, Gustavo A. Madero, Iztacalco, Iztapalapa, Magdalena Contreras, Miguel Hidalgo, Milpa Alta, Tlahuac, Tlalpan, and Xochimilco for their cooperation during our fieldwork and for providing data for the project. We are grateful to Hugo Delgado Granados, Gerardo A. Galguera Rosas, Vanesa Ayala Perea, and Viviana Torres Valle for their assistance in the administration of the project. We also, acknowledge Enrique Guevara Ortiz, Carlos Valdés González, Oscar Cepeda Ramos, and Leobardo Domínguez Morales of the Centro Nacional de Prevención de Desastres (CENAPRED), for sharing data and for encouraging the development of this research. Data were obtained from the following institutions: Servicio Sismológico Nacional, Instituto Nacional de Estadística y Geografía (INEGI), Secretaría de Comunicaciones y Transporte (SCT), Instituto Federal de Telecomunicaciones, Comisión Nacional del Agua (CONAGUA), Centro de Instrumentación y Registro Sísmico (CIRES), Comisión Nacional Forestal (CONAFOR), Secretaría de Educación Pública (SEP), Secretaría de Desarrollo Económico (SEDECO), Comisión Reguladora de Energía, and Instituto Federal de Telecomunicaciones (IFT). The Secretaría de Educación, Ciencia, Tecnología e Innovación (SECTEI) of CDMX funded this research (Convenio SECITI/112/2017). We also acknowledge the partial support from the National Autonomous University of Mexico under the "Programa de Apoyo a Proyectos de Investigación e Innovación Tecnológica (PAPIIT Projects No. IT102420, IN107321)" and the Consejo Nacional de Ciencia y Tecnología (CONACYT 2017-01-5955).

Author contributions D.A. Novelo-Casanova contributed to design, planning, supervision of the Atlas and estimates of social vulnerability, exposure, and risk; G. Suárez contributed to design, planning and supervision of the Atlas and estimation of seismic hazard and scenarios; E. Cabral-Cano, E.A. Fernández-Torres, E. Havazli and D. Solano-Rojas contributed to subsidence hazard; O.A. Fuentes-Mariles, E.D. López-Espinosa, and H.L. Morales-Rodríguez contributed to flood hazard; M.A. Jaimes contributed to seismic risk and scenarios; A.L. Martin-Del Pozzo and A. Nieto-Torres contributed to volcanic hazard and scenarios; S. R. Rodríguez-Elizarrarás and W.V. Morales-Barrera contributed to mass movement processes hazard; V.M. Velasco-Herrera contributed to forest fire hazard. 


\section{Declarations}

Conflict of interest The authors have no conflicts of interest to declare that are relevant to the content of this article.

Open Access This article is licensed under a Creative Commons Attribution 4.0 International License, which permits use, sharing, adaptation, distribution and reproduction in any medium or format, as long as you give appropriate credit to the original author(s) and the source, provide a link to the Creative Commons licence, and indicate if changes were made. The images or other third party material in this article are included in the article's Creative Commons licence, unless indicated otherwise in a credit line to the material. If material is not included in the article's Creative Commons licence and your intended use is not permitted by statutory regulation or exceeds the permitted use, you will need to obtain permission directly from the copyright holder. To view a copy of this licence, visit http://creativecommons.org/licenses/by/4.0/.

\section{References}

Abrahamson NA, Silva WJ (1997) Empirical response spectral attenuation relations for shallow crustal earthquakes. Seism Res Let 68:94-127

Aguilar J, Juarez H, Ortega R, Iglesias J (1989) The Mexico earthquake of september 19, 1985—statistics of damage and of retrofitting techniques in reinforced concrete buildings affected by the 1985 earthquake. Earthq Spec 5(1):145-151

Auvinet G, Méndez E, Juárez, M (2013) Soil fracturing induced by land subsidence in Mexico City. In Proceedings of the 18th International Conference on Soil Mechanics and Geotechnical Engineering, Paris, 2921-2924

Bard PY (1999) Microtremor measurements: a tool for site affects estimation? Effect of Surface Geology on Seismic Motion. Proc. 2nd Internat. Symp, Yokohama, Japan 1251-1279

Bjerrum L (1963) Allowable settlement of structures. Proc European Conference on Soil Mechanic and Foundation Engineering, Wiesbaden, Brighton, England, 135-137

Boyer ER (1975) La gran inundación: vida y sociedad en México (1629-1638), Secretaría de Educación Pública, México, SepSetentas, 218, $151 \mathrm{p}$

Buduma N, Locascio N (2017) Fundamentals of Deep Learning: Designing Next-Generation Machine Intelligence Algorithms. O'Reilly Media, Inc

Burland JB, Mair RJ, Standing JR (2004) Ground performance and building response due to tunnelling. In Advances in Geotechnical Engineering: The Skempton conference 291-342

Burrough PA, McDonnell RA (1998) Principles of geographical information systems. Oxford University Press, New York

Cabral-Cano E, Dixon TH, Miralles-Wilhelm F, Díaz-Molina O, Sánchez-Zamora O, Carande RE (2008) Space geodetic imaging of rapid ground subsidence in Mexico City. GSA Bull 120:1556-1566. https:// doi.org/10.1130/B26001.1

Cabral-Cano E, Solano-Rojas D, Oliver-Cabrera T, Wdowinski S, Chaussard E, Salazar-Tlaczani L, Cigna F, DeMets C, Pacheco-Martínez J (2015) Satellite geodesy tools for ground subsidence and associated shallow faulting hazard assessment in central Mexico. Proc IAHS 372:255-260. https://doi.org/ 10.5194/piahs-372-255-2015

Carrillo N (1948) Influence of artesian wells on the sinking of Mexico City. Proc Second Int Conf Soil Mech Found Eng 2:156-159

Chaussard E, Wdowinski S, Cabral-Cano E, Amelung F (2014) Land subsidence in central Mexico detected by ALOS InSAR time-series. Rem Sens Environ 140:94-106. https://doi.org/10.1016/j.rse.2013.08. 038

Cigna F, Tapete D (2021) Present-day land subsidence rates, surface faulting hazard and risk in Mexico City with 2014-2020 Sentinel-1 IW InSAR. Rem Sens of Environ. https://doi.org/10.1016/j.rse.2020. 112161

Córdova C, Martin-Del Pozzo AL, López CJ (1994) Paleoland forms and volcanic impact on the environment of prehistoric Cuicuilco, southern Mexico City. J Archaeol Sci 21:585-596

Courtland LM, Connor CB, Connor L, and Bonadonna C (2012) Introducing geoscience students to numerical modeling of volcanic hazards: The example of Tephra2 on VHub.org, Numeracy, 5(2), Article 6

Crichton D (1999) The risk triangle. In: Ingleton J (ed) Natural disaster management. Tudor Rose, England 
Cutter SL, Boruff BJ, Shirley WL (2003) Social vulnerability to environmental hazards. Soc Scien Quart $84: 242-261$

Damiani ML, Groppelli G, Norini G, Bertino E, Gigliuto A, Nucita A (2006) A lava flow simulation model for the development of volcanic hazard maps for Mount Etna (Italy). Comput Geosci 32:512-526

Denis DJ (2020) Univariate, bivariate, and multivariate statistics using R: quantitative tools for data analysis and data science. Willey Online Libr. https://doi.org/10.1002/9781119549963

Du Z, Ge L, Ng AH-M, Zhu Q, Zhang Q, Kuang J, Dong Y (2019) Long-term subsidence in Mexico City from 2004 to 2018 revealed by five synthetic aperture radar sensors. Land Deg Develop 30:1785-1801. https://doi.org/10.1002/ldr.3347

Duchon J (1977) Splines minimizing rotation invariant semi-norms in Sobolev spaces. In: Constructive Theory of Functions of Several Variables, Springer. Berlin 85-100, doi: https://doi.org/10.1007/BFb00 86566

Espinosa Aranda JM, Jiménez A, Ibarrola G, Alcantara F, Aguilar A, Henestroza M, Maldonado S (1995) Mexico City: seismic alert system. Seismol Res Lett 66:42-53

Fernández-Torres E, Cabral-Cano E, Solano-Rojas D, Havazli E, Salazar-Tlaczani L (2020) Land subsidence risk maps and InSAR based angular distortion structural vulnerability assessment: an example in Mexico City. Proc Int As Hydrol Sci, Copernicus GmbH 382:583-587. https://doi.org/10.5194/ piahs-382-583-2020

Ferrari L, Orozco-Esquivel T, Manea V, Manea M (2012) The dynamic history of the trans-Mexican volcanic belt and the Mexico subduction zone. Tectonophysics 522:122-149

Flores T, Camacho H (1922) Terremoto Mexicano del 3 de enero de 1920. Instituto Geológico Mexicano, Boletín 38. http:/bcct.unam.mx/bogeolpdf/geo38/

Galloway DL, Burbey TJ (2011) Review: regional land subsidence accompanying groundwater extraction. Hydrogeology 19:1459-1486. https://doi.org/10.1007/s10040-011-0775-5

García-Acosta V, Suárez G (1996). Los sismos en la historia de México, tomo I. Universidad Nacional Autónoma de México/Centro de Investigaciones y Estudios Superiores en Antropología Social. Fondo de Cultura Económica, 719

García-Palomo A, Carlos-Valerio V, López-Miguel C, Galván-García Concha-Dimas A (2006) Landslide inventory map of Guadalupe range, north of the Mexico Basin. Bol Soc Geol Mex. https://doi.org/10. 18268/bsgm2006v58n2a2

Gayol R (1925) Estudio de las perturbaciones que en el fondo de la Ciudad de México ha producido el drenaje de las aguas del subsuelo, por las obras del desagüe y rectificación de los errores a que ha dado lugar una incorrecta interpretación de los efectos producidos. Revista Mexicana De Ingeniería y Arquitectura 3:96-132

Gobierno del Distrito Federal (2004) Normas técnicas complementarias para diseño y construcción de cimentaciones. Gaceta Oficial del Distrito Federal, v. II, 103-BIS, 11-39

Goel MK (2011) Runoff Coefficient. In: Singh VP, Singh P, Haritashya UK (eds) Encyclopedia of snow, ice and glaciers. Encyclopedia of earth sciences series. Springer, Dordrecht

Herrera G, Ezquerro P, Tomás R, Béjar-Pizarro M, López-Vinielles J, Rossi M et al (2021) Global threats of a silent hazard: land subsidence due to groundwater extraction. Science 371:34-36

Hoberman L (1974) Bureaucracy and disaster: Mexico City and the flood of 1629. J Lat Am Stu 6:211-230

Hooper DM (1995) Computer-simulation models of scoria cone degradation in the Colima and MichoacánGuanajuato volcanic field, México. Geofis Int 34:321-340

Jaimes MA, García-Soto AD (2020) Ground-motion duration prediction model from recorded mexican interplate and intermediate-depth intraslab earthquakes. Bull Seismol Soc Am 20:1-16

Jaimes MA, Reinoso E, Ordaz M (2006) Comparison of methods to predict response spectra at instrumented sites given the magnitude and distance of an earthquake. J Earthq Eng 10:887-90

Jaimes MA, Ramirez-Gaytán A, Reinoso E (2015) Ground-motion prediction model from intermediatedepth intraslab earthquakes at the hill and lake-bed zones of Mexico City. J Earthq Eng 19:1260-1278. https://doi.org/10.1080/13632469.2015.1025926

Jaimes MA, Niño M (2017) Cost-benefit analysis to assess seismic mitigation options in Mexican public school buildings. Bull Earthq Eng 15(19):3919-3945. https://doi.org/10.1007/s10518-017-0119-5

Jiménez-Espinoza M (1996) Programa Ax. Área de Riesgos Hidrometeorológicos. Centro Nacional de Prevención de Desastres. México Instituto Nacional de Estadística, Geografía e Informática (National Institute of Statistics and Geography): Censo de Población y Vivienda [Census of Population and Housing 2010] (https://www.inegi.org.mx/programas/ccpv/2010/)

Lermo J, Chávez-García FJ (1994) Site effect evaluation at Mexico City: dominant period and relative amplification from strong motion and microtremor records. Soil Dyn Earthq Eng 13:413-423

Levi E (1990) History of the drainage of Mexico City. Int J Wat Res Develop. https://doi.org/10.1080/07900 629008722472 
López-Quiroz P, Doin M-P, Tupin F, Briole P, Nicolas J-M (2009) Time series analysis of Mexico City subsidence constrained by radar interferometry. J App Geophys 69:1-15. https://doi.org/10.1016/j.jappg eo.2009.02.006

Maloof MA (2005) Machine learning and data mining for computer security: Methods and applications. Advanced Information and Knowledge Processing, Springer

Martin-Del Pozzo AL (1982) Monogenetic volcanism in Sierra Chichinautzin. Mexico Bull Volcanol 45:9-24

Martin-Del Pozzo AL, Córdova C, Lopez J (1997) Volcanic impact on the southern basin of Mexico during the Holocene. Quat Int 43:181-190

Meyerhof GG (1956) Penetration tests and bearing capacity of cohesionless soils. J Soil Mech and Found Div 82:1-19

Mossoux S, Saey M, Bartolini S, Poppe S, Canters F, Kervyn M (2016) Q-LAVHA: a flexible GIS plugin to simulate lava flows. Comput Geosci 97:98-109. https://doi.org/10.1016/j.cageo.2016.09.003

Nakamura Y (1989) A method for dynamic characteristics estimation of subsurface using microtremor on the ground surface. Quart Rep Rail Tech Res Inst 30:25-33

Nieto-Torres A, Martin-Del Pozzo AL (2019) Spatio-temporal hazard assessment of a monogenetic volcanic field, near México City. J Volcan Geother Res 371:46-58

Nieto Torres A (2020) Evaluación del riesgo asociado al vulcanismo monogenético hacia la Ciudad de México. PhD Thesis, Earth Sciences, Universidad Nacional Autónoma de México

Ordaz M, Singh SK (1992) Source spectra and spectral attenuation of seismic waves from Mexican earthquakes, and evidence of amplification in the hill zone of Mexico City. Bull Seismol Soc Am 82:24-43

Osmanoglu B, Dixon TH, Wdowinski S, Cabral-Cano E, Jiang Y (2011) Mexico City subsidence observed with persistent scatterer InSAR. Int J App Earth Obs Geoinformation 13:1-12. https://doi.org/10. 1016/j.jag.2010.05.009

Pardo M, Suárez G (1995) Shape of the subducted Rivera and Cocos plates in southern Mexico: seismic and tectonic implications. J Geophys Res: Solid Earth 1978-2012(100):12357-12373

Rashed T, Weeks J (2003) Assessing vulnerability to earthquake hazards through spatial multicriteria analysis of urban areas. Int J Geo-Inf 17:47-576

Ricceri G, Soranzo M (1985) An analysis on allowable settlement of structures. Rivista Italiana di Geotecnica 4:177-188

Rosen PA, Gurrola E, Sacco GF (2012) The InSAR scientific computing environment, Proc 9th European Conference on Synthetic Aperture Radar, 730-733

Rosenblueth E, Arciniega A (1992) Response spectral ratios. Earthq Eng Struct Dyn 21:483-492

Rosenblueth E, Meli R (1986) The 1985 Mexico earthquake. Concr Int 8(5):23-34

Saaty RW (1980) The analytic hierarchy process, New York: McGraw Hill, Revised editions, Paperback Pittsburg: RWS Publications

Saaty RW (1987) The Analytic hierarchy process-what it is and how it is used. Matem Model 9:161-176

Santoyo E, Ovando E, Mooser F, León-Plata E (2005) Síntesis Geotécnica de la Cuenca del Valle de México, TGC Ediciones, Ciudad de México, Mexico, 171pp

Scaletti Cárdenas A (2018) Capital disasters and suspended moves: Mexico (1629) and Lima (1746). Quiroga 14:114-123

Siebe C (2000) Age and archaeological implications of Xitle volcano, southwestern basin of Mexico-City. J Volcan Geother Res 104(1-4):45-64

Siebe C, Rodríguez-Lara V, Schaaf P, Abrams M (2004) Radiocarbon ages of Holocene Pelado, Guespalapa, and Chichinautzin scoria cones, south of Mexico City: implications for archaeology and future hazards. Bull Volcan 66:203-225

Skempton AW, Macdonald DH (1956) The allowable settlements of buildings. Proc Inst Civ Eng, London 50:727-768. https://doi.org/10.1680/ipeds.1956.12202

Solano-Rojas D, Wdowinski S, Cabral-Cano E, Osmanoğlu B (2020) Detecting differential ground displacements of civil structures in fast-subsiding metropolises with interferometric SAR and band-pass filtering. Sci Rep 10:15460. https://doi.org/10.1038/s41598-020-72293-Z

Song Y, Gong J, Niu L, Li Y, Jiang Y, Zhang W, Cui T (2013) A grid-based spatial data model for the simulation and analysis of individual behaviours in micro-spatial environments. Simul Model Pract Theory 38:58-68

Sosa-Rodríguez FS (2010) Impacts of water-management decisions on the survival of a City: from ancient Tenochtitlan to modern Mexico City. Wat Res Develop 26:675-687

Stone WC, Yokel FY, Celebi M, Hanks T, Leyendecker EV (1987) Engineering aspects of the september 19, 1985 Mexico earthquake. NBS Build Sci Series 165:207 
Suárez G, Espinosa-Aranda JM, Cuellar A, Ibarrola G, García A, Zavala M, Maldonado S, Islas R (2018) A dedicated seismic early warning network: the mexican seismic alert system (SASMEX). Seism Res Lett 89(2A):382-391. https://doi.org/10.1785/0220170184

Suárez G, Novelo-Casanova DA (2018) A pioneering aftershock study of the destructive 4 january 1920 Jalapa, Mexico, earthquake. Seism Res Lett. https://doi.org/10.1785/0220180150

Suárez G, Novelo D, Mansilla E (2009) Performance evaluation of the seismic alert system (SAS) in Mexico City: a seismological and social perspective. Seism Res Lett 80:707-716

Suárez G, Caballero-Jiménez GV, Novelo-Casanova DA (2019) Active crustal deformation in the transmexican volcanic belt as evidenced by historical earthquakes during the last 450 years. Tectonics. https://doi.org/10.1029/2019TC005601

UNAM Seismology Group (1986) The September 1985 Michoacan earthquakes: Aftershock distribution and history of rupture. Geophys Res Lett 13 573-576

United Nations International Strategy for Disaster Reduction: Terminology on disaster reduction (2009). https://www.unisdr.org/files/7817_UNISDRTerminologyEnglish.pdf

Urbina F, Camacho H (1913) La zona megaséismica Acambay-Tixmadeje, estado de México: conmovida el 19 de noviembre de 1912 (Vol. 32). Imprenta y fototipia de la Secretaría de fomento, Mexico

Wahls HE (1981) Tolerable settlement of buildings. J Geotech Eng 109:1495-1496. https://doi.org/10.1061/ (ASCE)0733-9410(1983)109:11(1495.2)

Wood CA (1980) Morphometric evolution of cinder cones. J Volcanol Geotherm Res 7:387-413

Yunjun Z, Fattahi H, Amelung F (2019) Small baseline InSAR time series analysis: unwrapping error correction and noise reduction. Comput Geosc 133:104331. https://doi.org/10.1016/j.cageo.2019.104331

Publisher's Note Springer Nature remains neutral with regard to jurisdictional claims in published maps and institutional affiliations.

\section{Authors and Affiliations}

David A. Novelo-Casanova ${ }^{1}$ (D) Gerardo Suárez ${ }^{1}$ - Enrique Cabral-Cano ${ }^{2}$. Enrique A. Fernández-Torres ${ }^{3}$. Oscar A. Fuentes-Mariles ${ }^{4}$. Emre Havazli ${ }^{5}$. Miguel Á. Jaimes ${ }^{6}$ - Erika D. López-Espinoza ${ }^{7}$. Ana Lillian Martin-Del Pozzo ${ }^{8}$. Wendy V. Morales-Barrera ${ }^{9} \cdot$ Hipólito L. Morales-Rodríguez ${ }^{4} \cdot$ Amiel Nieto-Torres $^{3}$. Sergio R. Rodríguez-Elizarrarás ${ }^{9} \cdot$ Darío Solano-Rojas $^{10} \cdot$ Victor M. Velasco-Herrera $^{11}$

1 Departamento de Sismología, Instituto de Geofísica, Universidad Nacional Autónoma de México, Col. Ciudad Universitaria, Alcaldía Coyoacán, 04510 Ciudad de México, México

2 Departamento de Geomagnetismo y Exploración, Instituto de Geofísica, Universidad Nacional Autónoma de México, Col. Ciudad Universitaria, Alcaldía Coyoacán, 04510 Ciudad de México, México

3 Posgrado de Ciencias de La Tierra, Instituto de Geofísica, Universidad Nacional Autónoma de México, Col. Ciudad Universitaria, Alcaldía Coyoacán, 04510 Ciudad de México, México

4 Coordinación de Hidráulica, Instituto de Ingeniería, Universidad Nacional Autónoma de México, Col. Ciudad Universitaria, Alcaldía Coyoacán, 04510 Ciudad de México, México

5 Rosenstiel School of Marine and Atmospheric Science, University of Miami, 4600 Rickenbacker Cswy, Miami, FL 33149, USA

6 Coordinación de Ingeniería Estructural, Instituto de Ingeniería, Universidad Nacional Autónoma de México, Col. Ciudad Universitaria, Alcaldía Coyoacán, 04510 Ciudad de México, México

7 Departamento de Ciencias Atmosféricas, Centro de Ciencias de La Atmósfera, Universidad Nacional Autónoma de México, Col. Ciudad Universitaria, Alcaldía Coyoacán, 04510 Ciudad de México, México

8 Departamento de Vulcanología, Instituto de Geofísica, Universidad Nacional Autónoma de México, Col. Ciudad Universitaria, Alcaldía Coyoacán, 04510 Ciudad de México, México 
9 Departamento de Dinámica Terrestre Superficial, Instituto de Geología, Universidad Nacional Autónoma de México, Col. Ciudad Universitaria, Alcaldía Coyoacán, 04510 Ciudad de México, México

10 Facultad de Ingeniería, Universidad Nacional Autónoma de México, Col. Ciudad Universitaria, Alcaldía Coyoacán, 04510 Ciudad de México, México

11 Sección de Radiación Solar, Instituto de Geofísica, Universidad Nacional Autónoma de México, Col. Ciudad Universitaria, Alcaldía Coyoacán, 04510 Ciudad de México, México 